\title{
Credit Risk Management and the Financial Performance of Domiciled Banks in Sierra Leone: An Empirical Analysis
}

\section{Emerson Abraham JACKSON' ${ }^{\oplus}$, Edmund TAMUKE' ${ }^{\circledR}$}

\section{ABSTRACT}

This study assesses the nexus between credit risks and performance of commercial banks in Sierra Leone using data collected from the Bank of Sierra Leone (BSL) on relevant Financial Soundness Indicators like ROA, Bank Liquidity, NPL, and Credit over the 2008Q1-2018Q4 period. Evidence from (unbalanced) panel data estimation within the fixed effects model shows that the fragility of the banking system stems from high NPLs. We further provide evidence that a low productive base in the domestic economy influences the state of high NPLs in the banking system. The study revealed the need for collaboration between the research arm of monetary policy and financial stability departments in a bid to monitor risk in the financial system, which the entire banking system experienced around 2015-2017 that resulted in stringent measures adopted by the BSL to rescue the two state-own commercial banks. Equally, vigilant approaches should be explored by the BSL authority that leads to (positive) structural changes in banks' approach to improving efficiency while at the same time minimizing continued risks to high NPLs and many more. The study finally recommends that ROA and ROE be adopted as independent indicators by the regulatory authorities to effectively monitor performances across the banking industry, as this would help monitor unexpected shocks in the banking system.

Keywords: Credit Risk; Profitability; Non-Performing Loan; Panel Data; Sierra Leone

Jel Code: G21, G28, G32
${ }^{1}$ Research Economist, Research and Statistics Department, Bank of Sierra Leone, Freetown, Sierra Leone

ORCID: E.A.J. 0000-0002-2802-6152; E.T. 00000002-2320-6541

\section{Corresponding author/Sorumlu yazar:}

Emerson Abraham JACKSON,

Research and Statistics Department,

Bank of Sierra Leone,

Freetown, Sierra Leone

E-mail/E-posta:

ejackson1@bsl.gov.sl

\section{Submitted/Başvuru: 21.10.2021 \\ Revision Requested/Revizyon Talebi: 27.12.2021 \\ Last Revision Received/Son Revizyon: 07.01.2022 \\ Accepted/Kabul: 08.01.2022}

Citation/Atıf: Jackson, E.A., \& Tamuke, E. (2022). Credit risk management and the financial performance of domiciled banks in Sierra Leone: an empirical analysis. Iktisat Politikası Araştırmaları Dergisi - Journal of Economic Policy Researches, 9(1), 139-164.

https://doi.org/10.26650/JEPR1012975 


\section{Introduction}

Crises of all sorts took center stage in news headlines during the wake of the Global Financial Crisis (GFC) around 2007 - 2009; notable among these include high NonPerforming Loans (NPLs), mounting credit risks resulting in bank closures, recapitalization, and bailouts by governments and central banks were actioned to save the financial system from collapsing, while at the same time limiting the contagion impact of spill-overs to other sectors (Jackson \& Jabbie, 2019; Kapetanios, Mumtaz, Stevens \& Theodoridis, 2012; Reinhart \& Rogoff, 2008, 2009). The term 'Credit Risk (CR)' is used here to denote nonpayment of credit/loan issued to customers, which have a high probability of occurring when regulatory measures are relaxed or poorly monitored under normal condition and hence, resulting in a situation where banks are faced with considerable losses to their balance sheet account.

Banks' credit creation is considered the primary means of financial intermediaries/banks making money/profit. However, there are always risks attached to it when measures are relaxed to the extent that (all and sundry) customers are granted loan facilities without necessary security measures to recover liabilities. Credit risk management is a strategy that banks worldwide have resorted to in protecting bank balance sheets and depositors' savings. Relaxed regulatory measures typically result in what is perceived as institutional governance failure or, in short, systemic market failure (Jackson \& Jabbie, 2019).

The process of channeling surpluses from one sector of an economy into areas considered as highly indebted is what financial intermediaries have engaged themselves with for decades since the inception of banking operations all around the world (Boateng, 2019). Risk-taking is part and parcel of banking operation, but in developed economies like the UK and the USA, such risks are protected through stipulated deposits set aside by financial institutions. In most cases, such risks may be protected against through uptake of the insurance premium or writing-off bad debts to specialist institutions, normally referred to as 'factor' (Barone, 2019; Kargi, 2011).

The banking industry in Sierra Leone is still under-developed. Therefore, the only remedy to securing stakeholders' interests (savers and shareholders) is by ensuring stipulated cash reserves are set aside to write-off debt and ascertaining proof of collateral(s) from debtors in the event of non-payment of outstanding debt. However, in non-compliance with stipulated payment and the non-collateralization of appropriate debt instruments, there is a tendency for problems to spill-over into the real economy because of lapses in institutional policies, as recently witnessed in Sierra Leone.

A notable case of credit risk exposure to the financial system in Sierra Leone was witnessed in the early 1990s, with an immediate closure of the "International Bank of Trade 
and Industry (IBTI)" as ordered by the then Governor of the BSL on account of its alleged informal financing activities (Madhi, 2018). The closure of this bank and its operation was seen as easing spill-over effects of toxic transactions in the entire banking system, which would have been tantamount to a complete systemic failure in the country's financial system. One will attribute this to the 'modus operandi' of toxic customers and staff in some of the country's financial institutions who are in the habit of recycling loans and institutional collaboration of illegal financial operations even with bleak chances of recovering loan repayments. The Bank of Sierra Leone has made an effort to combat this situation by implementing drastic measures to halt loan issuance to "Politically Exposed Persons (PEPs)" and other identified toxic obligors as part of its obligation to combat money laundering, while at the same time protecting the financial system from further risky exposure (GIABA, 2010; Jackson, 2020a; Jackson, Barrie, \& Johnson, 2021).

When banks are faced with crises of high NPLs and other risky concerns, it requires intervention by the Central Bank. The Bank of England did an example of high NPLs intervention when the UK government bailout banking system during the global financial crisis in 2007-09, which continued for years under the technical term of Quantitative Easing, acronym $Q E$ (Kapetanios et al., 2012; Joyce et al., 2011). Equally in Sierra Leone, the Bank of Sierra Leone (BSL) has made several attempts to intervene through bailouts and replacement of strategic leadership (replaced by short-term oversight committees in stateowned commercial banks) in a bid to address its objectives of achieving price stability while also maintaining a balance on systemic risk to the country's financial system (BSL Act, 2019 and BSL Act 2011). High CR impacts the flow of credit typically to households and enterprises who are likely to be harshly hit, with the ultimate impact on the reduced prospect for investments and consumption. In the current age of the digital economy, this also affects the flow of payment systems while undermining confidence in a country's financial system through a reduced scope for savings, particularly capital mobility inflow (Kargi, 2011; OseiAssibey \& Bockarie, 2013; Boateng, 2019).

A plethora of empirical studies has attested to the fact that poor institutional/corporate governance and political meddling are to be blamed for the high level of NPL experienced across the commercial banking sector in Sierra Leone, which is also tied to poor credit management surveillance amongst practitioners (Jackson \& Jabbie, 2019; Caggiano et al., 2014; Osei-Assibey \& Bockarie, 2013; Kargbo \& Adamu, 2009; Demirgüç-Kunt \& Detragiache, 2005).

Recently and expressly in 2018, the Bank also set up a new department called the Financial Stability- the newly established department works collaboratively with the Banking Supervision department to minimize systemic risk in the financial system. These 
departments pursued efforts to monitor domestic commercial banks' operations in areas about NPL and credit risks, with the overall focus on restoring consumers' and investors' confidence in the financial system. However, amidst all these efforts by the central bank, credit risk is still a threat to the stability of the banking / financial system, which has the potential of undermining the fabrics of macroeconomic stability. Given the problems above, the researchers have developed their impetus in utilizing panel data methodology - this is to be backed by the use of relevant Financial Soundness Indicator (FSIs) compiled by the BSL to effectively assess commercial banks' performance and their efforts in effectively curbing systemic risks to the financial system on set criteria.

Furthermore, in order to address the core focus of this study, we have set ourselves the task of exploring/finding answers to the following research questions: (i) What is the impact of credit risk management on banks' profitability in Sierra Leone?; (ii) How do loan and advances affect banks profitability?, and (iii) What is the relationship between NPLs and profitability in Sierra Leonean banks?

Based on the research above questions, the study, which is aimed at addressing the impact of credit risk on bank performances in Sierra Leone, is set to achieve the following milestones or objectives: (i) Examine the relationship between the core variables constituting loan payment default and commercial banks' profitability in Sierra Leone; (ii) Examine the impact of credit risk on the profitability of Sierra Leonean banking system; (iii) Identify relationships between non-performing loans and banks' profitability; and (iv) Evaluate the effect of loan and advance on banks profitability on Sierra Leonean bank. Similar research endeavors have been explored in other countries, but not quite in Sierra Leone, given the uniqueness of the research to utilize Panel Data methodology in assessing banks' performances.

The remaining sections of the paper are divided as follows: Section two provides a stylized fact of commercial banks' credit and performance in Sierra Leone, while section three addresses literature background surrounding CR and performance of banks, subsectioned into theoretical and empirical literature. Section four addresses the methodology of exploring the exposition of CR in Sierra Leone's banking system. Section five presents the outcome of the results and discussion. Finally, six concludes with proffered recommendations for policy implementation from our findings.

2. Stylized Facts on Commercial Banks' CR Performance in Sierra Leone [20082018]

Commercial banking operation in Sierra Leone dates back to the colonial era of Great Britain's governance. During this period, there were notable UK allied institutions such as 
Standard Chartered and Barclays operating in the dormitory of the country's capital, which expanded to regional towns as well. Standard Chartered Bank Sierra Leone was established in 1894 to drive commerce and prosperity through diversity, and to date, its employee composition is $53 \%$ female gender biased (Standard Chartered Bank, n/d). On the other hand, Barclays was already in operation since 1917, with full incorporation as Barclay Bank Sierra Leone (BBSL) confirmed on March 15, 1971. As of 1997, the Barclays holding group had $60 \%$ of shares, but this whittled down $9 \%$ allocated to BBSL staff shares, while the remaining 51\% sold out to the Sierra Leone government (now incorporated as Rokel Commercial Bank) on account of the intensity of the civil crisis in the country (Barclays, $\mathrm{n} / \mathrm{d})$.

More recently, there has been a surge in commercial banks in the country, with two of them being state-owned, notably the Rokel Commercial Bank (RCB) and Sierra Leone Commercial Bank (SLCB), which commenced operation in the year 1973. In addition, the post-civil crisis has ushered influx of foreign-owned banks, particularly from the West African Sub-region. However, despite the growth in banking operations, the financial system has experienced credit crises because of lapses in managing deposits and loan issuances. Figure 1 below provides evidence of banks' total liabilities against total credit in the system, indicating Non-Performing Loan (NPL) crises the banking industry experienced over the period.

Figure 1. Trend in Deposit, Credit and Liabilities

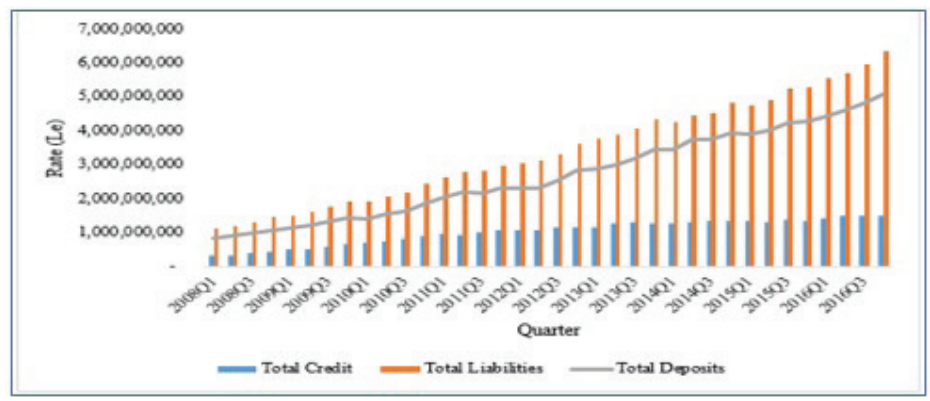

Source: Authors' Output from MS Excel

The banking system in Sierra Leone has gone through intense shocks, threatening business confidence and stability in the domestic economy. Currently, there are 14 commercial banks, 17 community banks, and two mobile services providers operating in the dormitory of the economy (BSL, 2020). Two of the commercial banks (notable Sierra Leone Commercial and Rokel Commercial Banks) are state-owned, which indicates a high level of public ownership in their operational activities. However, more recently (2016-2018), the efficiency of commercial banking operations was badly tarnished on account of political 
meddling, which nearly wrecked the entire banking system. In a bid to quell fears and expectations of future collapse in the banking system, the Bank of Sierra Leone (BSL) intervened with 'specific directives' ${ }^{1}$ on how the two state-owned institutions were to be managed, particularly when it comes to the disbursement of loans and the management or provisioning of bad debt.

After these constrained periods of financial system turmoil in the country, the banking system also witnessed a gradual increase in growth of gross loans and NPLs during the observed periods, as shown in Figure 2 below. The growth rate in the gross loan was positive during the period 2012 - 2013 but eased between 2013 and 2015 during the Ebola Virus Disease outbreak, which gave rise to a negative growth rate of 0.43 percent. Furthermore, an increase of 11.96 percent was registered in 2016 but declined to a 2.13 percent growth rate in 2017. That said, the main challenge to credit growth could be viewed from the lenses of a build-up of huge domestic debt arrears, the unstable macroeconomic conditions witnessed during the Ebola Virus Disease Outbreak, and backed by a high level of non-performing loans, among others. In 2018, Gross loans grew to 18.17 from 2.13 percent. This movement could increase liquidity in the banking system because of the massive injection of liquidity to MDAs and contractors engaged in (road) construction projects awarded by the government to achieve an infrastructural development drive. Regarding the sectoral distribution of loans, commerce and finance seem to bear the bulk of loans disbursed, followed by construction. However, the trend has continued, given the drive to foster infrastructural development.

Figure 2. Credit Risk in Terms of NPLs Net of Provisions and NPLs to Gross Loans

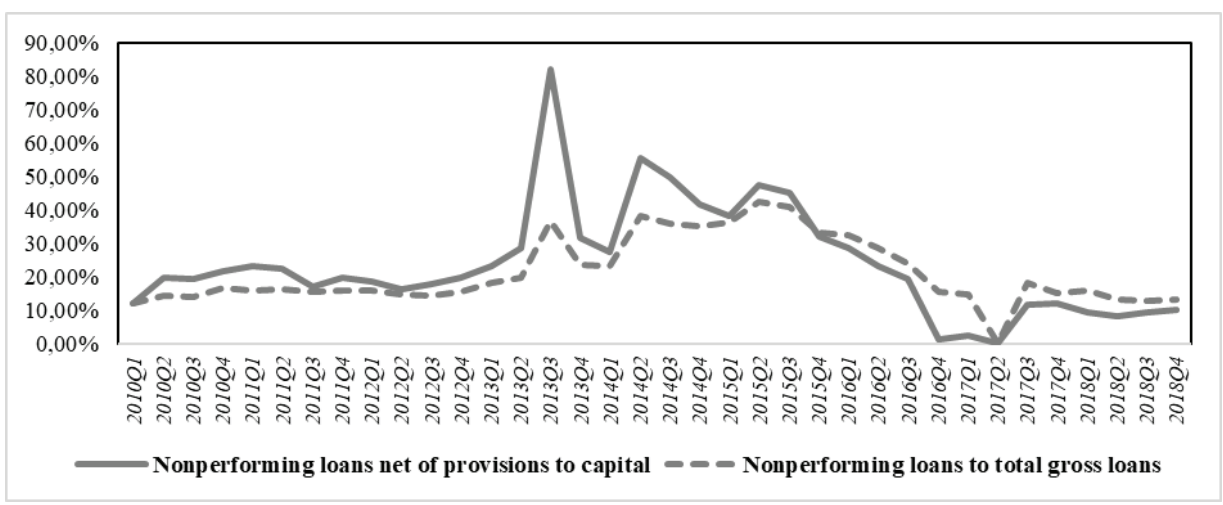

Source: Authors' Output from MS Excel

The financial system in Sierra Leone is yet to take a more aggressive course under the revised BSL Acts of 2019; creating a Financial Stability department is now making it possible for effective operations to be well coordinated. Such an operational role incorporates

\footnotetext{
${ }^{1}$ This included the establishment of an interim oversight committee management and resident supervisors to monitor credit operations in the two state-own banks. In addition, there were public notices made in the media that prevented loans being granted to Politically Exposed Persons (PEPS).
} 
issuing licenses and managing micro and macro-prudential risk operations in the entire banking system. Further to this, the appointment of a Second Deputy Governor as provisioned in the BSL Act 2019 is a step in the right direction to support the effective monitoring of the country's financial system. Furthermore, such operational management will soon be supported by the formation of a Financial Policy Committee (FPC), which supposedly is expected to engage in extensive research to monitor risks in the financial system through activities like stress testing and the construction of structural models that take cognizance of a mixture of financial soundness and macroeconomic indicators.

\section{Literature Review}

Credit risk is associated with failings on the part of an obligor [be it single or joint] to adhere to stipulated terms of a contract with a financial intermediary/bank. This is common worldwide, but failure on the part of an obligor/debtor to meet stipulated payment(s) seems to be higher in developing economies, as noticed more lately in Sierra Leone, where legislative procedures and credit management processes have been meddled with. This has raised mounting questions about the central bank's autonomy to use its regulatory power in responding to crises, and specifically credit risks, which have ramifications for economic melt-down (Warburton \& Jackson, 2020). There are myriad factors responsible for credit risk in an economy and to name a few, high unemployment rate, exogenous shocks as witnessed more recently with COVID-19, and changes in socio-economic conditions, linked with political masterminding of financial institutions in an economy (Jackson, 2020; Thakor, 2016, Calomiris \& Haber; 2014; Kargi, 2011; Faia, 2010). In pursuance of exploring the impacts of credit risks on banks' performance, various researchers across the world have embarked on theoretical and empirical research activities as identified below in the literature review sub-components.

\subsection{Theoretical Review}

Sound management of credit risk framework is an essential element for banks to champion the objective focus of profitability and their guaranteed survival in a competitive market environment (Bhattaria, n/d). The fundamental principles in the credit risk management process, as highlighted by Lindgren (1987), include the following: establishment of a clear structure, allocation of responsibility, prioritization of processes and discipline, with clearly defined responsibilities communicated and accountability (also addressed in Bhattaria, $\mathrm{n} / \mathrm{d}$ ). In addition, using an effective quantitative model is considered vital in explaining default risks, evaluating the relative degree of importance of the factors, improving the pricing of default risk, screening out bad loan applicants, and calculating reserve needed to meet expected future loan losses (Brownbridge, 1998). However, even 
though credit risk is perceived as a potential threat to the survival of commercial banks, Margrabe (2007) observed a lag in the operationalization of applying modern portfolio theory when it comes to the management of credit risk.

According to Thakor (2014), it is perceived that an interesting stylized fact about banking is to do with the evaluation and pricing of risk by bankers and other market participants' reactions over the business cycle. Based on an excerpt from Krainer (2004), also cited in Thakor (2014: p. 1), it is proved that credit spread shrinks during expansion and expands during economic contractions/periods of recession. This is attributed to several reasons, of which equity risk premia is thought to vary throughout a business cycle. More specifically, Bekaert et al. (2013) documented evidential proof to show that it is driven (at least) in part by changes in risk aversion that are correlated with monetary policy changes and other forms of shocks reported in the "balance-sheet channel", that are thought to impact on changes in the distribution of wealth.

Thakor (2016: 24) made an outstanding attempt in the development of a theoretical proposal for credit risk management throughout a business cycle - this is based on 'rational learning, 'which leads to revision in inferences of banking skills depending on the macro state, shaped by investors' sentiment or development in the real sector. In such a setting, a sufficiently long sequence of favorable outcomes for banks could lead all agents (incorporating commercial banks, investors, and regulators) to assign relatively high probabilities to the ability of banks to manage their risks. In short, this makes it possible to offer low-cost funding while also encouraging banks to engage in riskier lending. However, this has proven to reveal an increase in the risk premium, particularly on risky assets. While the rational learning theory approach seems quite convincing, further research is needed to develop a better understanding through formal means, with potential interaction between the rational learning model as addressed by Thakor and the political economy hypothesis proposed by Calomiris and Haber (2014). Such interaction of theoretical propositions is sure to impact unearthing various annoying issues associated with banking regulations while opening up new questions for future research endeavors.

Hao et al. (2010, p. 48) used electronic search to address some underpinnings around the concept of CR modeling, which ranged from purely theoretical, mathematical to econometric approaches. In this, the underlying motive has been on issues around risk measures, with attention focused on losses, given the state of defaults. It was particularly noticed that long before their research was pursued, most techniques used in credit risk modeling incorporated estimation using three parameters, namely 'the probability of default $(P D)$, the loss given default (LGD), and the correlation across defaults and losses' (Crouhy et al., 2000). It is emphasized that the first two risk parameters, PD and LGD, are critical elements of the 
Internal Rating Base (IRB) approach, considered vital to Basel II (Basel Committee on Banking Supervision, 2006). The IRB, as mentioned, makes it possible for banks to compute capital charges for each exposure from their estimate of the PD and LGD (Hao et al., ibid).

Underpinned on the grounds of macroeconomic foundation, Faia (2010) constructed a Dynamic Stochastic General Equilibrium (DSGE) model to address the impact of credit risk transfer on the macroeconomy. In summary of her research outcome, which was built along the lines of Holmstrom and Tirole (1997) and Parlour and Plantin (2008), Faia examined the model's properties with and without active secondary markets for credit risk transfer. It was observed that the possibility of transferring credit reduces the impact of liquidity shocks on banks' balance sheets, with the ultimate impact on a reduction in bank incentives to monitor risks. In short, this made it possible for secondary markets to release bank capital and also exacerbated the effect of productivity and other macroeconomic shocks on output and inflation. In conclusion, she noticed that an offer of capital recycling, with the scope of reducing bank monitoring and secondary credit markets in general equilibrium, will make it possible for banks to take on more risk.

\subsection{Empirical Review}

In pursuit of empirical outcomes, Mekasha (2001) investigated credit risk management and its impact on Ethiopian Commercial Banks; the study utilized a 10-year panel data from the selected commercial banks by examining the relationship between mlReturn on Asset / Ratio of Profit after Tax to Total Assets (ROA) and loan provision, non-performing loans, and total assets. The outcome revealed a significant relationship between bank performance and credit risk management.

Based on a study conducted for the Middle East and North African (MENA) countries around 1989 - 2005, Ben-Naceur and Omran (2008) examined the influence of bank regulations, concentration, financial and institutional development on commercial banks' margin and profitability. The outcome of their study proved that bank capitalization and credit risk have a positive and significant impact on banks' net interest margin, cost efficiency, and profitability.

The effect of credit risk management on profitability in Kenya was also assessed by a study conducted by Kithinji (2010). Data utilized for the study covered the amount of credit, level of non-performing loans and profits, and the period under investigation captured 2004 to 2008. In his findings, it was revealed that the bulk of the profits of commercial banks was not influenced by the amount of credit and non-performing loans, which therefore suggest that other variables other than credit and non-performing loans could be responsible for published accounts on profits reported by commercial banks in the country. 
Kargi (2011) used data like financial ratios as measures of bank performance and credit risk collected from the annual reports and accounts of six sampled banks from 2004-2008 in Nigeria. Using descriptive analysis, backed by correlation and regression techniques, the findings revealed that credit risk management has a significant impact on banks' profitability in Nigerian. The conclusion shows that banks' profitability inversely influenced the levels of loans and advances, non-performing loans, and deposits, thereby exposing banks to the risk of illiquidity and distress.

The impact of credit risk management on the financial performance of commercial banks in Kenya was carried out by Fredrick (2012) using CAMEL model as a proxy for credit risk management. The outcome proved the strong impact of CAMEL (which includes credit risk components) on the financial performance of commercial banks in the country. Equally, Boateng (2019) also used the CAMEL model to determine credit risk management on banks' performance in Ghana, and the findings showed that earnings stood out as the highly significant factor affecting the performance of banks in Ghana.

Kolapo et al. (2012) carried out an empirical investigation into the quantitative effect of credit risk on commercial banks' performance in Nigeria over 11 years $(2000$ - 2011) using a cross-sectional panel data model. Their results show that the effect of credit risk on bank performance measured by the ROA of banks is cross-sectional invariant; this indicates that the effect is similar across banks in the country, despite the degree to which individual banks are affected is not captured by the method of analysis that was employed in the study. It also shows that a 100 percent increase in NPL reduces bank profitability by about 0.65 percent, while a 100 percent increase in loan loss provision also reduces profitability by about 9.6 percent. The recommendation from the study specifies that banks in Nigeria should improve their capacity in both credit analysis and loan administration. At the same time, a high level of vigilance is paid by the regulatory authority in ensuring that banks are compliant with relevant provisions of the Bank and Financial Institutions Act (WTO, 1999) and prudential guidelines.

Osei-Assibey and Bockarie (2013) carried out a country-specific study to investigate the effect of risk premium, leverage ratio, and credit risk on banks' loan supply in Sierra Leone. In order to achieve their desired outcome(s), they applied the design of annual bank-level data on an unbalanced panel of 13 commercial banks over ten years $(2002-2011)$ by employing a time and bank-specific fixed effects model for estimation. The findings from their study indicate that risk premium, the share of non-performing loans in the banks' loan portfolio, tier 1 capital ratio (leverage ratio), and local currency deposit levels positively and significantly affect the share of loan supply to the private sector in banks' earning assets. It was also proved that advances to local currency deposit ratio and bank size have significant 
negative effects on the share of loans in banks' assets. The study finally proposed salient recommendations, which stressed that monetary authority (the Bank of Sierra Leone), banking practitioners, and the government should be very vigilant in their attention to key risk factors such as NPLs and risk premium in the operation of the banking sector as a way of boosting the supply of commercial banks loan.

Furthermore, assessment of credit risk management on banks' profitability in Nigeria was done by Kurawa and Garba (2014); this was done with the view of ascertaining the extent to which default rate (DR), cost per loan assets (CLA), and capital adequacy ratio (CAR) influence banks' profitability (ROA). The researchers made use of secondary data sourced from the annual reports and accounts of the specified banks from 2002 to 2011, and the results from random-effect generalized least square (GLS) regression techniques revealed that default rate (DR) ratio and cost per loan assets (CLA) ratio had indicated a significant positive relationship with the dependent variable, in this case, ROA. Furthermore, the control variable (LOAN) seems to have executed a positive relationship with ROA, while AGE returned a negative association with ROA. In summary of their study, it was concluded that credit risk management components positively affect banks' profitability in Nigerian.

Moving into the east of Asia, Kodithuwakku (2015) produced outcomes on their empirical analysis of the impact of credit risk management on the performance of the commercial banks in Sri Lanka by applying primary and secondary data. ROA was used as a performance indicator, while loan provision to total loan (LP/TL), loan provision to nonperforming loans (LP/NPL), loan provision to total assets (LP/TA), non-performing loans/ total loans (NPL/TL) were indicators of credit risk. The result shows that non-performing loans and provisions adversely impact profitability.

Djalilov and Piesse (2016) investigated the determinant of bank profitability in both the early and late transition countries of Central and Eastern Europe (CEE) and the former USSR. The study applied a GMM technique for the period covering 2000-2013. The result shows that profitability persists, and the determinants of bank profitability vary across transition countries, more so on account of commercial banks' competition in early transition countries. In addition, the study noted the positive impact of credit risk on bank profitability in early transition countries, but negative in late transition countries; government spending and monetary freedom were negatively seen to be influencing bank profitability only in late transition countries. Also, highly capitalized banks were more profitable in early transition countries, thereby implying robustness in these banking sectors. Finally, a range of possible approaches for government intervention was proposed as part of the findings.

Tan et al. (2017) used a two-step generalized method of moment system estimator to 
examine the impacts of risk, competition, and cost efficiency on the profitability of a sample of Chinese commercial banks over the period 2003-2013. The study proved that Chinese commercial banks with higher levels of insolvency risk have higher profitability (ROA and ROE). Finally, higher competition leads to lower profitability in the Chinese banking industry, and Chinese commercial banks with higher levels of cost efficiency have lower ROA. This signifies a structure-conduct-performance paradigm rather than the efficientstructure paradigm in the Chinese banking industry. The study also found out that apart from a general picture of the Chinese banking industry's risk, efficiency, and competition conditions, valuable information on the part of the Chinese Government was needed to address regulatory control in the banking industry.

Contemporary pursuance by Kaseem and Sakr (2018) using OLS regression analysis examined the relationship between bank-specific characteristics and bank's profitability for a sample of 19 Egyptian banks during the period 2007-2016. The findings revealed that bank size and loan loss provision ratio are the main determinants of profitability, given a significant relationship with all profitability measures. The capital ratio shows a significant relationship with ROA and NIM but insignificant with ROE, while the Loan ratio and deposit ratio have an insignificant effect on the bank's profitability.

More recently again, Kara et al. (2019) assessed the effect of securitization activity on relative credit quality by using a uniquely detailed dataset from the euro-denominated syndicated loan market. The study is supported by two additional methodologies to control for predetermined borrower-lender matching - it is unearthed that at issuance, which is based on observable characteristics, banks do not seem to select and securitize loans of lower credit quality. With securitization, the credit quality of borrowers whose loans are checked deteriorates more than those in the control group. The authors also found out that poorer performance by borrowers of securitized loans seems to be connected to banks' reduced monitoring incentives.

In pursuance of addressing concerns around credit risks by commercial banks, Jackson et al. (2021) recently examined the impact of exchange rate and inflation on the performance of commercial banks in Sierra Leone. The study used macroeconomic data like Inflation and Exchange and bank-specific data like Return on Equity and Return of assets. In addition, Auto-Regressive Distributed Lag (ARDL) model was used to explore the objectives, and the findings indicate that inflation has a positive effect on banking sector performance. However, the exchange rate exerts a negative spill-over effect on the overall economy at the same time. Given the persistence of inflationary pressures, which normally have a direct spill-over effect on macroeconomic and commercial banks' performance in a small-open economy like Sierra Leone, the study recommends a high level of collaboration between the monetary and 
government authorities in a bid to address crises concerned with exchange rate pressure adequately. Such an approach will make it worthwhile for the banking system to serve its purpose of championing sustained growth and development while ensuring risks to the country's financial system are constantly monitored at all times.

Critically, the above literature reviews (theoretical and empirical) have helped shape the authors' direction of exploring the study. Many of the studies explored have highlighted failings on the part of commercial banks to monitor risks, which range from failings on the part of management to take cognizance of competition, high government spending, and the lack of proper credit analysis by banks. In light of the previous literature reviews, this paper is intended to add value to an existing body of knowledge by exploring historical data for (all qualifying) commercial banks to assess credit risks and performance of banks, which have implications for both price and financial stability. It is hoped that the specific methodology (Panel Data), which has never been explicitly explored in the case of Sierra Leone, will make a value addition to an existing body of future studies.

\section{The Methodology [incorporating Description of Data]}

\subsection{Model Specification and Estimation Technique}

The model adopted for this study is underpinned by the works of Kargi (2011), who utilized Ordinary Least Squares regression and Funso, Kolade, and Ojo (2012) that made use of Panel Data to explore "Credit Risk and the Performance of Nigerian Banks." This study seeks to add value by taking account of the specific situation with credit risk and commercial banks' performance in Sierra Leone over a defined study period (2008Q12018Q4), and specifically with premium paid to the criteria for bank selection. However, the estimation data was restricted to the identified period due to difficulties accessing specific Financial Soundness Indicators (FSIs) from high street banks across the country.

$$
R O A=\beta_{0}+\beta_{1}\left(\frac{N P L}{L A}{ }_{i t}\right)+\beta_{2}\left(\frac{L A}{T D_{i t}}\right)+\beta_{3}\left(\frac{T L}{T D_{i t}}\right)+\mu_{i}+\varepsilon_{i t}
$$

The anticipated 'a priori expectation' for this model is that all independent variables should bear a negative relationship on bank performance measured by Return on Assets (ROA) except loans and advances, which is expected to show a positive relationship with bank performance. Based on equation 1 above:

$\mathrm{ROA}=$ Ratio of profit after tax to total assets;

NPL/LA = Ratio of Non-performing loan to loan \& Advances;

LA/TD = Ratio of Loan \& Advances to Total deposit; 
$\mathrm{TL} / \mathrm{TD}=$ Ratio of Total loan to Total Deposit

$\beta_{0}-\beta_{3}=$ Coefficient

$\mu_{i}=$ Indiviual effect

$\boldsymbol{\varepsilon}_{i t}=$ Error Term.

Given the specificity of the Fixed Effects technique used in the model, proven by the Hausman test, we now provide a simplified expression using a variable of interest as shown in Equation 2 below:

$$
R O A=\beta_{0}+\beta_{1} N P L_{i t}+\beta_{2} C R_{i t}+\beta_{3} B l i q_{i t}+\mu_{i}+\varepsilon_{i t}
$$

\subsection{Sources Data and Variable Description}

\subsubsection{Data Sources}

The study applied both historical and descriptive analysis to assess the pattern of the credit risk of commercial banks in Sierra Leone [SL]. The sampled banks were based on the non-probability method as set out in the following criteria:

- A consistent set of data is available over the study period.

- No merger acquisition occurred during the study period, including both local and foreign-owned commercial banks.

- $\quad$ The banks are registered to trade under the banking act of Sierra Leone.

In consideration of the above-stated criteria, eight banks were selected out of the 14 domicile banks based on the above-stated criteria. Data collected spanned 2008Q1 2018Q4, sourced from Annual Reports and Accounts of all domicile banks.

\subsubsection{Variable Description}

\section{Ratio of Profit after Tax to Total Assets (ROA):}

Return on total assets (ROA) ratio measures earnings from a business investment before interest and taxes relative to its total net assets. It shows the effectiveness of assets used to create earnings.

Therefore, $\boldsymbol{R} \boldsymbol{O} \boldsymbol{A}=\frac{\boldsymbol{E} \boldsymbol{B I T}}{\text { Average } \text { Total Asset }}$

where EBIT $=$ Earnings before Interest and Taxes. 
The higher the earnings realized from business investment, the more influential the business will be in its asset usage. Hence, the ROA expressed as a percentage or sometimes decimal indicates money generated from a given amount of Leone currency invested into the business, in the case of banks' operation.

\section{Ratio of Non-Performing Loan to Loan and Advances [NPL / LA]:}

A Non-Performing Loan (NPL / LA) is borrowed money upon which the debtor has failed to make scheduled payments for a specified duration. Depending on the classification used or specified by regulators like the Bank of Sierra Leone (BSL) and the terms of the loan taken out, "Nil payment" meant that nothing had been paid on the principal and interest. In general, the required period for NPL classification will be 90 days or 180 days.

$$
\text { Therefore, } \boldsymbol{N P L} / \boldsymbol{L} \boldsymbol{A}=\frac{\text { Total NPL }}{\text { Total Outstanding Loans }}
$$

To an economist and more so where Monetary Policy decision is to be taken in addressing objective(s) around price stability, NPL ratios can be used to determine the state of a country's financial soundness/sign of instability in the financial market. In this regard, a potential investor will be most keen on using the NPL ratios to decide where to invest cash at a particular point in time. Hence, banks with low NPL ratios are considered lower-risk than those with high ratios.

\section{Ratio of Total Loan and Advances to Total Deposits (a proxy for Credit Risk) [CR /} TD]:

The loan-to-deposit ratio (LA / TD) assesses banks' liquidity by comparison with the total loans to total deposits during the same period. The LA / TD expressed as a percentage meant that high ratios indicate that banks do not have enough liquidity to address unforeseen liquidity requirements or survive in times of stress/shocks. On the other hand, (too much of) low ratio is an indication that banks are not be earning enough.

$$
\text { Therefore, } \boldsymbol{C R}=\frac{\text { Total Loan+Advances }}{\text { Total Deposits }}
$$

LA / TD ratio is an indication of banks' ability to cover loan losses and also, withdrawals made by customers. Investors mostly monitor the LA / TD ratio to ensure banks are liquid enough to cover loans in the event of economic stresses arising from loan defaults. Through this, banks can be better positioned to attract and retain (good) customers. Intuitively, the process on which LA / TD ratio is determined needs to be well managed to ensure banks do not retain deposits, with the need to lend out to potential customers will almost be tantamount to losses where interests on deposits are to be paid. 


\section{Bank Liquidity Ratio (Total Loans/Total Deposit)}

This ratio is used to compare a bank's total loans to its total deposits over the same period. The Loan to Deposit Ratio (abbreviated as BLiq) is expressed as a percentage. Therefore, a high ratio means banks are not sufficiently liquid to cover unplanned shocks. In a bid to avoid such situations, which normally result in financial system instability, banks are required to keep a certain amount of their deposits to cover unforeseen shocks as directed by the latest Basel agreement (Schneider, Schröck, Koch \& Schneider, 2017).

$$
\text { Therefore, Bliq }=\frac{\text { Total Loan }}{\text { Total Deposits }}
$$

\section{Empirical Results and Discussion}

The Summary Statistics and model Estimation results can be found in Table 1 and 2, respectively. The summary statistics provided in Table 1 show that all sampled banks are profitable based on their mean values but limited when compared to higher values attached to independent variables like CR and BLiq. This indicates that banks' profitability is highly hinged on the independent variables. The high standard deviation for ROA indicates that performance among commercial banks (particularly in terms of their ability to manage risks) varies from one bank to the other. The negative standard deviation values ascribed to the independent variables indicate that their outcomes affect profit significantly in the model. This shows that financial instability could be an emerging problem in the banking system if measures are not set in place to address ongoing risks. Both the Min and Max values for all four indicators seem encouraging for banks, indicating that internal management of the system could make it worthwhile for banks to minimize risks through engineered structural changes that lead to increased profitability (see Decker, 2012).

Table 1: Summary Statistics

\begin{tabular}{lccccc}
\hline Variable & Obs & Mean & Std. Dev. & Min & Max \\
\hline InROA & 335 & 2.451748 & 1.005175 & -1.622809 & 4.319671 \\
InNPL & 336 & 1.455203 & 0.4561799 & -1.251903 & 2.849473 \\
InCR & 336 & 3.798282 & 0.4112386 & -.2303929 & 3.985415 \\
InBliq & 334 & 3.645982 & 0.5800984 & 1.546581 & 4.93994 \\
\hline
\end{tabular}

Source: STATA Estimation Output

In a bid to ascertain the preciseness of the initial output from Panel Data estimation, we ran an estimation test as shown in the result outcome in Appendix 1. This pre-test estimation result shows that the F-probability value rejected the null hypothesis of homogeneity - a justification that the OLS model is not the preferred choice for the study; hence, heterogeneity made the Panel data technique the appropriate way to go. By isolating the OLS as proven from the pre-test estimation, there is an alternative that the possible outcome could either be 
Fixed Effect (FE) or Random Effect (RE) 'unbalanced panel data'² as indicated by models (2) and (4), respectively in Table 2 below.

Further to the above explanations, we also made use of the Hausman Test (a reference to Table 3), which shows a rejection of the Null Hypothesis at the 5\% level of significance this finally justifies preference for the Fixed Effects model ( $F E \_R O A-$ as shown in Table 2). The FE model, also known as the 'within estimator,' controls all time-invariant differences between individuals. As noted in the objectives, our preference for the Fixed Effects model demonstrates its high explanatory power in effectively interpreting coefficient values for assessing banks' credit risk level and profitability. However, the post-estimation test shows that Model 2, Fixed Effects (FE_ROA), has an autocorrelation problem. Hence, we corrected it using the adjusted standard errors, which produced the fixed effect standard error as demonstrated in Model 3, also demonstrated in table 2 above (FE_ROA_ADJ_STD_ER) see appendix 3.

Table 2: Panel Data Estimation Output

\begin{tabular}{|c|c|c|c|c|}
\hline & (1) & (2) & (3) & (4) \\
\hline VARIABLES & OLS_ROA & FE_ROA & FE_ROA_ADJ_STD_ER & RE_ROA \\
\hline $\ln N P L$ & $\begin{array}{c}-0.475 * * * \\
(0.103)\end{array}$ & $\begin{array}{l}-0.160 * \\
(0.0861)\end{array}$ & $\begin{array}{c}-2.337 * * * \\
(0.735)\end{array}$ & $\begin{array}{l}-0.177 * * \\
(0.0868)\end{array}$ \\
\hline $\operatorname{lnCR}$ & $\begin{array}{c}-1.050 * * * \\
(0.115)\end{array}$ & $\begin{array}{c}-0.727 * * * \\
(0.105)\end{array}$ & $\begin{array}{c}-8.324 * * * \\
(1.245)\end{array}$ & $\begin{array}{c}-0.756 * * * \\
(0.105)\end{array}$ \\
\hline InBliq & $\begin{array}{c}0.326^{* * *} \\
(0.0810)\end{array}$ & $\begin{array}{c}-0.228 * * \\
(0.108)\end{array}$ & $\begin{array}{c}1.418 \\
(1.193)\end{array}$ & $\begin{array}{l}-0.158 \\
(0.104)\end{array}$ \\
\hline Constant & $\begin{array}{c}5.947 * * * \\
(0.524)\end{array}$ & $\begin{array}{c}6.283 * * * \\
(0.520)\end{array}$ & $\begin{array}{c}47.77 * * * \\
(1.666)\end{array}$ & $\begin{array}{c}6.158 * * * \\
(0.542)\end{array}$ \\
\hline Observations & 333 & 333 & 326 & 333 \\
\hline R-squared & 0.282 & 0.169 & & \\
\hline Bank effect & YES & YES & YES & YES \\
\hline Periodid effect & $\mathrm{NO}$ & $\mathrm{NO}$ & NO & $\mathrm{NO}$ \\
\hline rmse & 0.856 & 0.660 & 5.503 & 0.668 \\
\hline F-test & 43.18 & 21.80 & 19.30 & \\
\hline Prob $>$ F & 0 & 0 & $\mathbf{0}$ & \\
\hline $\begin{array}{l}\text { Number of } \\
\text { crossid }\end{array}$ & & 8 & 8 & 8 \\
\hline F-test $\left(u \_i=0\right)$ & & 33.14 & 3.775 & \\
\hline
\end{tabular}

2 Unbalanced Panel Data estimation was applied owing to the existence of missing data provided, which also warrant the need to justify the data range as data were mostly unavailable for many of the banks beyond $2018 \mathrm{M} 12$. The alternative of a system General Moment and Methods (GMM) model was not a possibility given the small nature of the number of banks $(\mathrm{N})$ selected based on the criteria (reference to Section 4.3.1). 


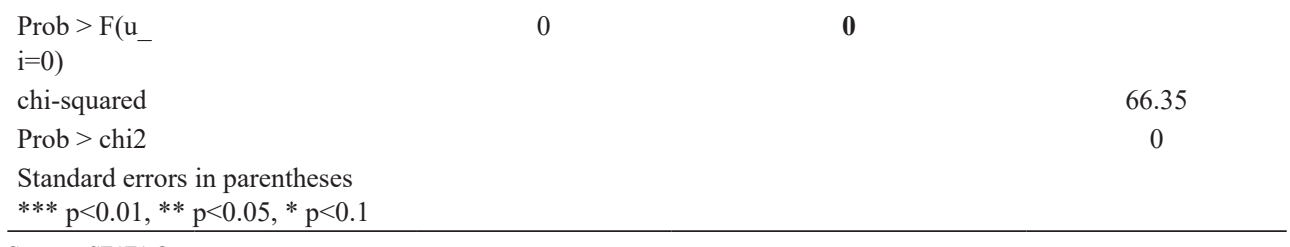

Source: STATA Output

Table 3: Hausman Test

\begin{tabular}{lcc}
\hline & Coefficients & \\
\hline & Fixed_ROA & Random_ROA \\
\hline InNPL & -0.1599254 & -0.1769331 \\
InCR & -0.7272652 & -0.7561919 \\
InBliq & -0.2281192 & -0.1575139 \\
Chi Square $=10.62$ & & \\
Prob. Value $=0.0140$ & & \\
Chosen Model: Fixed Effects Model & \\
\hline
\end{tabular}

Source: STATA Estimation Output

From the model outcome, there is sufficient evidence to justify the model's consistency with theory or a priori expectations, also attested in Kargi (2011), Funso et al. (2012), and Sriyono and Nabellah, (2020) studies. By interpretation, a 1\% increase in NPL can reduce ROA by ' $2.3 \%$ ' 3 , which indicates a strong level of significance (at 1\%, 5\%, and 10\%). Internal weaknesses in the system could also account for such outcomes/results, where banks are considered ill-equipped to monitor NPLs. In view of such an outcome, one would easily be poised to assume that internal culpability is engineered by (some) staff to connive with debtors in a bid to derail institutional efficiency.

In furtherance to addressing the objectives (specific to Objective 3), Table 2 also shows that a $1 \%$ increase in Credit Risk ( $\operatorname{lnCR}$ ) has the power of reducing ROA by $8.32 \%$, which is somehow high in reality. This indicates that the entire banking system is inclined to be issuing more loans than it is receiving from customers as deposits. This has the potential of reducing the profit level and asset position of banks, particularly in times of shocks as witnessed in the current era of COVID-19, where businesses and the general economy are seen to be showing signs of shrinkage on account of projected shocks to the global economy (Hidayat, Masyita, Nidar, Ahmad \& Syarif, 2022). This also portrays bleak hope of dividend payments to shareholders due to fragility in the banking system to remain sustainably liquid in meeting customers' demand.

With respect to banks' liquidity (BLiq) position in covering unplanned shocks, a $1 \%$ increase in the BLiq coefficient has the power of increasing ROA by $1.41 \%$ age point, but not

\footnotetext{
3 Please note that for lnNPL coefficient interpretation and likewise for lnCR and lnBliq, the use of log in all three variables has determined the interpretation of percentage value outcome.
} 
statistically significant. This means that BLiq has minimal or no relevance in explaining the liquid position of banks in addressing situations of acute or intense shocks. As stipulated under the Basel agreement (2006), which requires banks to keep a specific amount of their assets to cover undue circumstances, it is possible that the outcome from the BLiq indicator could render the financial system in a state of crisis. This can also activate spill-over effect in the entire economy because of the myriad of challenges associated with loss of confidence in the banking system, thereby resulting in possible redundancy, social problems, and many more. This could also be associated with the continued appetite of commercial banks to secure more of their cash assets in a high-interest Treasury Bills (T-Bills) market instead of intermediating in products that are relevant in preventing the financial system from collapsing.

In a bid to justify the robustness of the model output, we also went further by conducting post-estimation procedures starting with auto-correlation test - with this, the Null Hypothesis of no auto-correlation was rejected, indicating the presence of autocorrelation as evidenced in Appendix2. However, an effort was made to correct this shortcoming with the robust standard error test, as demonstrated in Appendix 3. Despite the advantage of the Panel Data technique in limiting multicollinearity, we decided to pursue an effort to prove the outcome of no multicollinearity. In furtherance of this, we proceeded by utilizing the Variance Inflation Factor (VIF) test, which accounts for the existence of multicollinearity in the model as outlined in Appendix 4. Based on the test outcome, all VIF values for the dependent variables are within a comfortable range of 'One,' which indicates no correlation. This thereby renders multicollinearity less of an issue in the model's outcome - an essential indication of satisfying objective 'One' for this study, which is to examine the relationship between the core variables constituting loan defaults and banks' profitability in Sierra Leone.

\section{Conclusion and Policy Recommendations}

This paper is perceived as a novelty, particularly in the case of Sierra Leone, where key Financial Soundness Indicators (FSIs) have been used to determine banks' profitability and risks to the country's financial system stability. The study has provided analyses of the macro-state of risk profile and banks' performances, with only eight banks adequately satisfying the criteria for estimation as set out in Section 4.3.1.

The result shows fragility in the country's banking system on account of high NPLs and its continued risks, which could be attributed to poor management of banks to assess liquidity requirements by customers to meet daily transaction needs. It is also evident that, while banks are highly focused on taking advantage of interest rates hike in the risk-free T-Bills money market, they are almost perceived as being in denial of the buoyant state of customers' cash 
transaction requirements in the domestic market to support buoyant economic activities. On the flip side of things, low-level production in the domestic economy and added to insufficient revenue collection by revenue generating institutions like the National Revenue Authority (NRA) revenue authority in meeting government's debt and other essential obligations (e.g., delayed payments to contractors) could also explain the spiraling rate of NPLs across the banking system.

On an equal note, the study outcome also brought to light the importance of a pursued effort to deepen financial stability research and backed by the BSL's ongoing commitment to establishing a Financial Policy Committee (FPC) in monitoring the country's financial risks system. Therefore, the sentence above is considered forward-looking in effectively addressing the core objectives of the central bank, which include price and financial stability. Furthermore, the negative coefficient signs in the independent variables (except BLiq) are consistent with a priori expectations, supporting empirical efforts in the West African Sub-region and elsewhere (Kargi, 2011; Funso et al., 2012; Kani, 2017; Ekinci and Poyraz, 2019).

To enhance the model's applicability, further research is needed to explore outcomes from independent indicators like ROE and ROA in effectively measuring commercial banks' profitability and creditworthiness. In addition, an extension of data or time scale (whenever available) will also be very useful in providing a more realistic picture of the state of credit crises with commercial banks in Sierra Leone. There is certainly a need for collaboration between the research arm of monetary and financial stability departments to monitor risk in the financial system, as witnessed around the period 2015-18, which resulted in the BSL intervening in the entire banking system (Jackson \& Jabbie, 2019). Equally, as proffered by Decker (2012), vigilant approaches should be explored by the BSL authority that leads to (positive) structural changes in banks' approach to improving efficiency while at the same time minimizing continued risks to high NPLs and many more.

Peer-review: Externally peer-reviewed.

Author Contributions: Conception/Design of Study- E.A.J.; Data Acquisition- E.A.J., E.T.; Data Analysis/Interpretation- E.T., E.A.J.; Drafting Manuscript- E.A.J., E.T.; Critical Revision of Manuscript- E.A.J., E.T.; Final Approval and Accountability- E.A.J., E.T.

Conflict of Interest: The authors have no conflict of interest to declare.

Grant Support: The authors declared that this study has received no financial support.

Acknowledgment: At this juncture, we wish to express appreciation to Mr. Morlai Bangura (Director of Monetary Policy Department) and Dr. Robert Korsu (Director of Research and Statistics Department) for their technical input in reading through the final output while at the same time providing relevant suggestions on how best to improve the overall quality of the study. We also wish to express our sincere appreciation to two anonymous reviewers for their critical comments on the work. 


\section{References}

Barclays. (n/d). Barclays Bank in Sierra Leone. Retrieved September 10, 2021, from https://www.archive.barclays. com/items/show/5349.

Barone, A. (2019). Factor. Retrieved July 28, 2021, from https://www.investopedia.com/terms/f/factor.asp.

Basel Committee on Banking Supervision. (2006). Basel II: International convergence of capital measurement and capital standards: A revised framework - comprehensive version. Bank of International Settlements. Retrieved June 20, 2021, from http://www.bis.org/publ/bcbs128.htm.

Bekaert, G., Hoerova, M., \& Lo Duca, M. (2013). Risk, uncertainty and monetary policy. Journal of Monetary Economics, 60(7), 771-788.

Ben-Naceur, S., \& M. Omran. (2008). The effects of bank regulations, competition, and financial reforms on MENA banks profitability. Economic Research Forum, Working Paper No. 44.

Bhattaria, Y.R. (n/d). Effect of credit risk on the performance of Nepalese Commercial Banks. Retrieved August 15, 2021, from https://pdfs.semanticscholar.org/2e79/19dea4a0534bc6a6b634d4ab8e2b4fcc8fle.pdf.

Brownbridge, M. (1998). The causes of financial distress in local banks in Africa and implications for prudential policy. UNCTAD/OSG/Discussion Paper, No 132. Retrieved September 10, 2921, from http://www.unicc.org/ unctad/en/pressref/prdis.htm.

Boateng, K. (2019). Credit risk management and performance of banks in Ghana: the "Camels" rating model approach. International Journal of Business and Management Invention, 8(2), 41-48.

BSL. (2020). Financial stability report 2018. Retrieved July 10, 2021, from http://www.bsl.gov.s1/FSR_2018.pdf.

BSL. (2019). The bank of Sierra Leone act 2019. Retrieved December 19, 2021, from http://www.bsl.gov.sl/ Bank\%20of\%20Sierra\%20Leone\%20Ascent\%202019.pdf.

BSL. (2011). The bank of Sierra Leone act 2011. Retrieved June 26, 2021, from http://www.bsl.gov.s1/BSL_ Act_2011.pdf.

Caggiano, G., Calice, P., \& Leonida, L. (2014). Early warning systems and systemic banking crises in low income countries: A multinomial logit approach. Journal of Banking and Finance, 47, 258-269. https://doi. org/10.1016/j.jbankfin.2014.07.002.

Calomiris, C. W., \& Haber, S. H. (2014). Fragile by design: The political origins of banking crises and scarce credit. New Jersey, USA: Princeton University Press.

Crouhy, M., Galai, D., \& Mark, R. (2000). A comparative analysis of current credit risk models. Journal of Banking and Finance, 24(1-2), 59-117.

Decker, O.S. (2012) Structural change and competition in the Sierra Leone banking sector: An empirical investigation. In O. E. G. Johnson (Ed.), Economic Challenges and Policy Issues in Early 21st century Sierra Leone (pp. 121-162). International Growth Centre, London, UK. Retrieved August 8, 2021, from http://www. theigc.org/wp-content/uploads/2012/03/Johnson-Ed.-2012-.pdf.

Demirgüç-Kunt, A., \& Detragiache, E. (2005). Cross-country empirical studies of systemic bank distress: A survey. IMF Working Paper WP/05/96. Retrieved January, 10, 2022, from www.citeseerx.ist.psu.edu/viewdoc/ download?doi=10.1.1.599.1909\&rep=rep1\&type=pdf.

Djalilov, K., \& Piesse, J. (2016). Determinant of bank profitability in transition countries: What matters most? Research in International Business and Finance, 38, 69-82. https://doi.org/10.1016/j.ribaf.2016.03.015.

Ekinci, R., \& Poyraz, G. (2019). The effect of credit risk on financial performance of deposit banks in Turkey. Procedia Computer Science, 158, 979-987. https://doi.org/10.1016/j.procs.2019.09.139.

Faia, E. (2010). Credit risk transfers and the macroeconomy. European Central Bank Lamfalussy Fellowship Programme, Working Paper Series No. 1256. Retrieved June 11, 2021, from https://www.ecb.europa.eu/pub/ pdf/scpwps/ecbwp1256.pdf?0a787f2607066b48feb0344fd8374559. 
Fredrick, O. (2012). The impact of credit risk management on financial performance of commercial banks in Kenya. DBA Africa Management Review, 3(1), 22-37.

Funso, K. T., Kolade., A. R., \& Ojo, O. M. (2012). Credit risk and commercial banks' performance in Nigeria: A panel model approach. Australian Journal of Business and Management Research, 2(2), 31-38.

GIABA. (2010). Anti-money laundering and combatting the financing of terrorism. Retrieved August 5, 2021, from https://fiu.gov.s1/downloads/2017-08/sierra-leone-third-mer-2010.pdf.

Hao, C., Moudud, A., \& Carling, K. (2010). Review of the literature on credit risk modelling: Development of the past 10 years. Banks and Bank Systems, 5(3), 43-60.

Hidayat, T., Masyita, D., Nidar, S. R., Ahmad, F., \& Syarif, M. A. N. (2022). Early warning early action for the banking solvency risk in the COVID-19 pandemic era: A case study of Indonesia. Economies, 10(6): 1-21. https://doi.org/10.3390/economies10010006.

Holmstrom, B., \& Tirole, J. (1997). Financial intermediation, loanable funds and the real sector. Quarterly Journal of Economics, 112(1997), 663 - 691.

Jackson, E. A., Barrie, M. S., \& Johnson, L. (2021). Impact of exchange rate and inflation on commercial banks' performance in Sierra Leone. Journal of Smart Economic Growth, 6(3), 67-95.

Jackson, E. A. (2020). Emerging innovative thoughts on globalization amidst the contagion of COVID-19 (pp. 1-19). In W. L. Filho., A. Azul., L. Brandli., \& P. G. Özuyar. (Eds.), Industry, Innovation and Infrastructure (pp. 1-18), Encyclopedia of Sustainable Development Goal, Springer Nature Publisher. https://doi.org/10.1007/9783-319-71059-4_131-1.

Jackson, E.A. (2020a). Importance of the public service in achieving the UN SDGs (pp. 1-19). In W. L. Filho, et al. (Eds.). Decent Work and Economic Growth, Encyclopedia of Sustainable Development Goal: Springer Nature Publisher. https://doi.org/10.1007/978-3-319-71058-7_20-2.

Jackson, E. A., \& Jabbie, M. (2019). Understanding market failure in the developing country context (pp. 1-14). In, W. L. Filho (Eds.), Decent Work and Economic Growth, Encyclopedia of Sustainable Development Goals: Springer Nature Publisher. https://doi.org/10.1007/978-3-319-71058-7_44-1.

Joyce, M. A. S., Lasaosa, A., Stevens, I., \& Tong, M. (2011). The financial market impact of quantitative easing in the United Kingdom. International Journal of Central Bank, 7(3), 113-161.

Kargbo, S. M., \& Adamu, P. A. (2009). Financial development and economic growth in Sierra Leone. Journal of Monetary and Economic Integration, 9(2), 30-61.

Kargi, H. S. (2011). Credit risk and the performance of Nigerian banks. Retrieved June 20, 2021, from https://www. academia.edu/8637351/CREDIT_RISK_AND_THE_PERFORMANCE_OF_NIGERIAN_BANKS_BY.

Kapetanios, G., Mumtaz, H., Stevens, I., \& Theodoridis, K. (2012). Assessing the economy-wide effects of quantitative easing, The Economic Journal, 122(564), F316-F347. https://doi.org/10.1111/j.1468-0297.2012.02555.x.

Kara, A., Marques-Ibanez, D., \& Ongena, S. (2019). Securitization and credit quality in the European market. European Financial Management, 25(2), 407-434. https://doi.org/10.1111/eufm.12168.

Kani, S. (2017). Credit risk and bank performance: Evidence from WAEMU Countries. IOSR Journal of Economics and Finance, 8(1), 5-11.

Kaseem, N. M., \& Sakr, A. (2018). The impact of bank-specific characteristics on the profitability of commercial banks in Egypt. Journal of Finance and Bank Management, 6(2), 76 - 90. https://doi.org/10.15640/jfbm. v6n $2 \mathrm{a} 8$.

Kithinji, A.M. (2010). Credit risk management and profitability of commercial banks in Kenya. Retrieved January 16, 2022, from http://hdl.handle.net/11295/40437.

Kodithuwakku, S. (2015). Impact of credit risk management on the performance of commercial banks in Sri Lanka. International Journal of Scientific Research and Innovative Technology, 2(7), 1-6. 
Kolapo, T. F., Ayeni, R. K., \& Oke, M. O. (2012). Credit risk and commercial banks' performance in Nigeria: A panel model approach. Australian Journal of Business and Management Research, 2(2), 31-38.

Krainer, John. (2004). What determines the credit spread? FRBSF Econ. Lett, No. 2004-36 Retrieved July 18, 2021 from https://www.frbsf.org/economic-research/files/e12004-36.pdf.

Kurawa, J.M. \& Garba. S. (2014). An evaluation of the effect of credit risk management (CRM) on the profitability of Nigerian Banks. Journal of Modern Accounting and Auditing, 10(1), 104-115.

Lindgren, H. (1987). Banks, investment company, banking firms, Stockholm Enskilda Bank (1924-1945). Institute for Research in Economic History, Stockholm School of Economics, Stockholm.

Madhi, I. (2018). Informal finance in Sierra Leone: Why and how it fits into the financial system. Retrieved July 19, 2021, from https://www.findevgateway.org/sites/default/files/publication_files/informal_finance_in_sierra_ leone-working_paper_i.m_final_160718_1.pdf.

Margrabe, K. (2007). The incidence of secured debt: Evidence from the small business community. Journal of Financial and Quantitative Analysis, 24, 379-394.

Mekasha, G. 2001. Credit risk management and its impact on performance on Ethiopian commercial banks. Addis Ababa University.

Osei-Assibey, E., \& Bockarie, B. A. (2013). Bank risks, capital and loan supply: Evidence from Sierra Leone. Journal of Financial Economic Policy, 5(3), 256-271. https://doi.org/10.1108/JFEP-09-2012-0041.

Parlour, C., \& Plantin, G. (2008). Loan sales and relationship banking. Journal of Finance, 63, 1291-1314.

Reinhart, C. M., \& Rogoff, K. S. (2009). The aftermath of financial crises. American Economic Review, 99(2), 466-72. https://doi.org/10.1257/aer.99.2.466.

Reinhart, C.M., \& Rogoff, K.S. (2008). Banking crises: An equal opportunity menace. National Bureau of Economic Research, Working Paper 14587.

Schneider, S., Schröck, G., Koch, S., \& Schneider, R. (2017). Basel “IV”: What's next for banks? Implications of intermediate results of new regulatory rules for European banks. Retrieved September 10, 2021, from https:// www.mckinsey.com.br/ /media/mckinsey/business\%20functions/risk/our\%20insights/basel\%20iv\%20 whats $\% 20$ next $\% 20$ for $\% 20$ european $\% 20$ banks/basel-iv-whats-next-for-banks.pdf.

Sriyono, S., \& Nabellah, A. (2020). Can credit quality as a moderating variable in increasing profitability: Study on conventional commercial banks listed on the Indonesia stock exchange. Jurnal Siasat Bisnis, 26(1), 23-35. https://doi.org/10.20885/jsb.vol26.iss1.art2.

Standard Chartered Bank. (n/d). Overview. Retrieved June 13, 2021, from https://www.sc.com/sl/about-us/.

Tan, Y., Floros, C., \& Anchor, J. (2017). The profitability of Chinese banks: impacts of risk, competition and efficiency, Review of Accounting and Finance, 16(10), 86-105. https://doi.org/10.1108/RAF-05-2015-0072.

Thakor, A.V. (2014). Bank capital and financial stability: An economic trade-off or a faustian bargain? Annual Review of Financial Economics, 6, 185-223. https://doi.org/10.1146/annurev-financial-110613-034531.

Thakor, A. V. (2016). The highs and the lows: A theory of credit risk assessment and pricing through the business cycle. Journal of Financial Intermediation, 25(2016), 1-29. https://doi.org/10.1016/j.jfi.2015.06.003.

Warburton, C. E. S., \& Jackson, E. A. (2020). Monetary responses to exogenous perturbations: The case of a small open economy (2007 - 2018). PSL Quarterly Review, 73(293), 181-201. https://doi.org/10.13133/20373643_7 3.293_5.

WTO. (1999). Bank and financial institutions act (1999). Retrieved January 15, 2022, from https://www.wto.org/ english/thewto_e/acc_e/lbr_e/wtacclbr5_leg_1.pdf. 


\section{APPENDICES}

Appendix 1: Result of Homogeneity / Poolability Test

\begin{tabular}{|c|c|}
\hline VARIABLES & $\ln R O A$ \\
\hline $\operatorname{lnNPL}$ & $\begin{array}{l}-0.160 * \\
(0.0861)\end{array}$ \\
\hline $\operatorname{lnCR}$ & $\begin{array}{c}-0.727 * * * \\
(0.105)\end{array}$ \\
\hline InBliq & $\begin{array}{c}-0.228^{* *} \\
(0.108)\end{array}$ \\
\hline 2.crossid & $\begin{array}{c}-0.530 * * * \\
(0.149)\end{array}$ \\
\hline 3.crossid & $\begin{array}{c}0.602 * * * \\
(0.150)\end{array}$ \\
\hline 4.crossid & $\begin{array}{c}-0.407 * * * \\
(0.156)\end{array}$ \\
\hline 5.crossid & $\begin{array}{c}0.526 * * * \\
(0.162)\end{array}$ \\
\hline 6.crossid & $\begin{array}{l}-0.277 \\
(0.177)\end{array}$ \\
\hline 7.crossid & $\begin{array}{c}1.077 * * * \\
(0.147)\end{array}$ \\
\hline 8.crossid & $\begin{array}{c}1.390 * * * \\
(0.175)\end{array}$ \\
\hline Constant & $\begin{array}{c}5.983 * * * \\
(0.525)\end{array}$ \\
\hline Observations & 333 \\
\hline R-squared & 0.583 \\
\hline $\begin{array}{l}\text { Standard errors in parentheses } \\
* * * \mathrm{p}<0.01, * * \mathrm{p}<0.05, * \mathrm{p}<0.1 \\
\text { testparm i.crossid } \\
\text { (1) } 2 . \mathrm{crossid}=\mathbf{0} \\
\text { (2) } 3 . \mathrm{crossid}=\mathbf{0} \\
\text { (3) } 4 . \mathrm{crossid}=\mathbf{0} \\
\text { (4) } 5 . \text { crossid }=\mathbf{0} \\
\text { (5) } 6 . \mathrm{crossid}=\mathbf{0} \\
\text { (6) 7.crossid }=\mathbf{0} \\
\text { (7) } 8 . c r o s s i d=0\end{array}$ & \\
\hline
\end{tabular}

Source: STATA Estimation Output 


\section{Appendix 2: Wooldrigde Test of Autocorrelation}

* xtserial lnROA $\operatorname{lnNPL}$ lnCR InBliq

$\mathrm{H}_{0}$ : no first-order autocorrelation

$\mathrm{F}(1,7)=\quad 21.026$

Prob $>\mathrm{F}=\quad 0.0025$

Source: STATA Estimation Output

\section{Appendix 3: Correction for Autocorrelation using the Adjusted Standard Error Test}

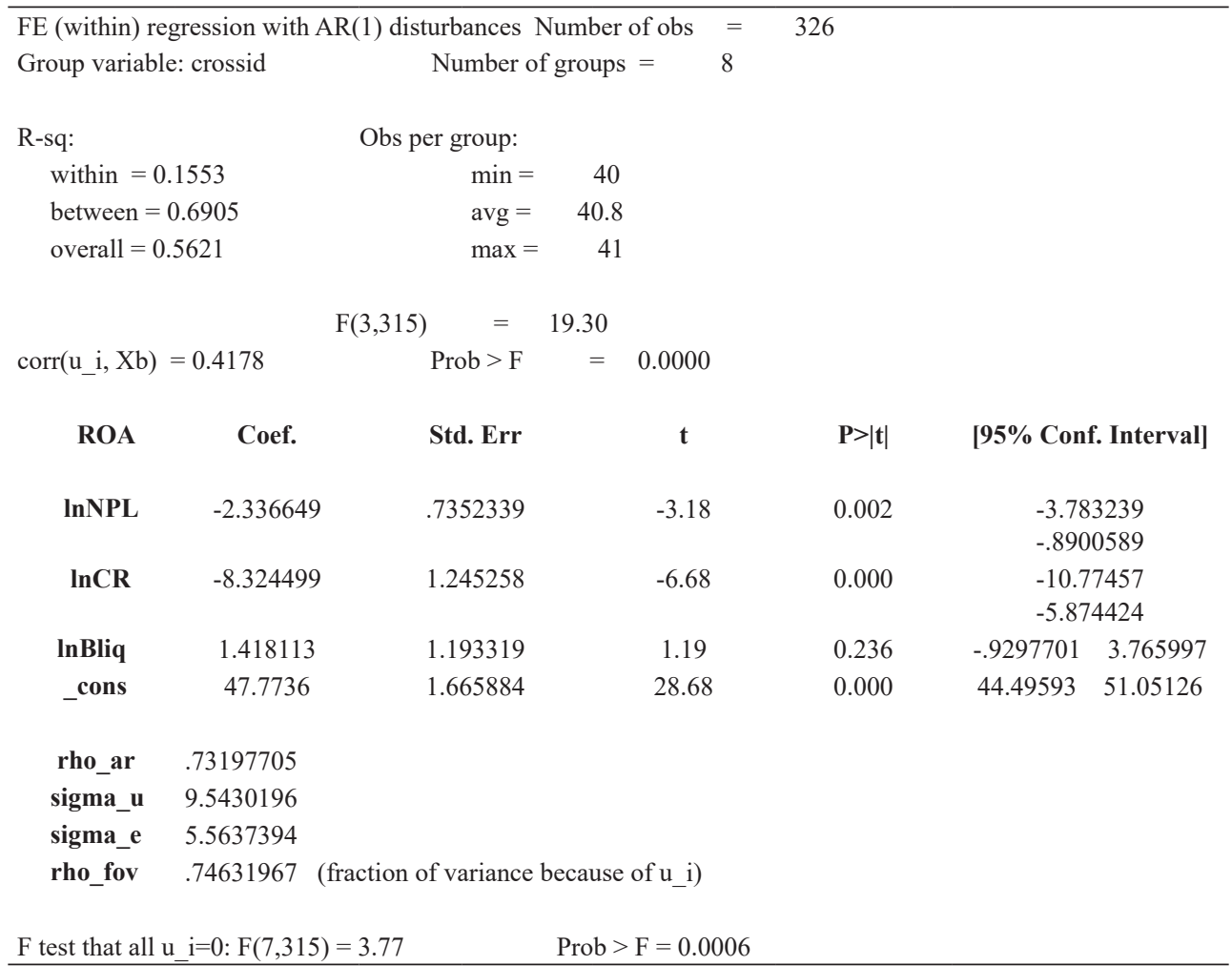

Source: STATA Estimation Output 
Appendix 4: Variance Inflation Factor (VIF)

\begin{tabular}{lcc}
\hline Variable & VIF & $\mathbf{1 / V I F}$ \\
\hline InCR & 1.02 & 0.983429 \\
InNPL & 1.01 & 0.985872 \\
InBliq & 1.00 & 0.997307 \\
Mean VIF & 1.01 & \\
\hline
\end{tabular}

Source: STATA Estimation Outcome 